\author{
МОДЕЛІ ФІНАНСУВАННЯ ЗАКЛАДІВ ВИЩОЇ ОСВІТИ \\ У КРАÏHАХ ЄВРОПИ
}

\title{
FUNDING MODELS OF HIGHER EDUCATION INSTITUTIONS IN THE EUROPEAN COUNTRIES
}

Розкрито інноваційні моделі розподілу фонансових ресурсів на вищу освіту. Вони включають фрінансування на основі попиту та пропозичії. Фінансування на основі пропозиції передбачає пряме фрінансування закладів вищої освіти. Фінансування на основі попиту містить непряме фрінансування закладів вищої освіти. До інструментів прямого фрінансування відносять: performance contracts (контракти за результатами діяльності), performance set-asides (виконання планових потреб). До інструментів непрямого фрінансування відносять: income-contingent student loans (студентські кредити на основі доходів), human capital contracts (контракти на людський капітал), universal vouchers (універсальні ваучерu), lifelong learning accounts (рахунки для навчання впродовж життя). Встановлено, що за моделі фрінансування на основі пропозиції фрінансування закладів вищої освіти здійснюється з державних джерел, виходячи з потреб «на вході» (input-based allocation) $i$ не враховуючи критеріїв результативності. За моделі фрінансування на основі попиту система орінансування грунтується переважно на ринкових механізмах, відповідно до яких державні фонансові ресурси «слідують за студентом», а не спрямовуються безпосередньо до закладів вищої освіти. Визначено три виміри (pillars) моделей фонансування у країнах Європи, а саме: "Basic funding" (базове фрінансування), "Performanceoriented funding" (результат-орієнтоване фрінансування), "Innovation-/profile-oriented funding" (інноваційно-/профрільно-орієнтоване фрінансування). З'ясовано, що "Basic funding" (базове фрінансування) надається у вигляді блокового гранту. Інструментами фрінансування є такі: "historical funding" (фрінансування на історичній основі/історично визначеного розподілу); "input-oriented formula (study places)" (формула фрінансування з вхідними показниками/навчальні місця, зокрема кількість студентів); "performance agreements" (контракти за результатами діяльності); "vouchers" (ваучерu). Розкрито критері належної моделі фрінансування (good financing model) та принципи належного фрінансування (good funding) у сорері вищої освіти.

Ключові слова: базове фрінансування, результат-орієнтоване фрінансування, інноваційно-/профрільно-орієнтоване срінансування, контракти за результатами діяльності, студентські кредити на основ доходів, контракти на людський капітал, ваучери.

Innovative models of financial resources allocation for higher education are revealed. These include: supply-side and demand-side funding. Supply-side funding involves direct funding of higher education institutions. Demand-side funding contains indirect funding of higher education institutions. Direct funding instruments include: performance contracts, performance set-asides. Indirect funding instruments include: income-contingent student loans, human capital contracts, universal vouchers, lifelong learning accounts. Supply-side funding model provides funding for higher education institutions from state sources on the input-based allocation and without taking into account the performance criteria. According to the Demand-side funding model funding system is predominantly based on market mechanisms whereby public financial resources "follow by the student" and not directed to higher education institutions. Three pillars of funding models in European countries have been identified, namely: "Basic funding", "Performance-oriented funding", "Innovation-/profile-oriented funding". It is found out that Basic funding is provided as a block grant. Funding instruments are: "historical funding", "input-oriented formula (study places)", "performance agreements", "vouchers". The criteria of a good financing model and the principles of good funding in higher education are revealed. The criteria of a good financing model are: mobilise sufficient resources, public and private, to meet the needs for quantitative expansion and quality improvement on an equitable basis; guarantee that cost-sharing is always accompanied by adequate student aid; rely on funding mechanisms that are performance-based and, when appropriate, allocated in a competitive manner; ensure full compatibility among the various funding instruments used; offer transparency in the design and operation of all funding mechanisms (policy objectives sought, rules of procedures for resource allocation)

Key words: basic funding, human capital contracts, income-contingent student loans, innovation-/profile-oriented funding, performance contracts, performance-oriented funding, vouchers.
Постановка проблеми у загальному вигляді. У країнах Європи проводяться реформи у сфері вищої освіти, що спрямовані на забезпечення автономії університетів. Цей процес супроводжується появою нових механізмів моніторингу результатів діяльності університетів, фрінансування та якості у сорері вищої освіти. «Рефрорма фрінансування вищої освіти має на меті досягнення фрінансової стабільності для розширення можливостей надання вищої освіти і вдосконалення якості та релевантності пропонованих програм. Стійке фрінансування $€$ ключовою умовою для збалансованого розвитку вищої освіти» [1, с. 317]. За цих умов постає необхідність розглянути моделі фрінансування закладів 
вищої освіти у країнах Європи, що мають значний рівень фрінансової автономії.

Аналіз останніх досліджень і публікацій, на які спирається автор, в яких розглядають цю проблему і підходи до її розв'язання. Особливості результат-орієнтованого орінансування у країнах Європи проаналізовано $\mathrm{H}$. de Boer, B. Jongbloed [2], питання інноваційних механізмів у фрінансуванні вищої освіти перебуває у центрі уваги F. Ziegele [3], тенденції у фрінансуванні закладів вищої освіти країн Європи розглянуто J. Salmi, A. Hauptman [4].

Виділення не вирішених раніше частин загальної проблеми. Дослідники переважно акцентували увагу на фрормах та методах фрінансування закладів вищої освіти, а питання моделей їх фрінансування залишається не досить розкритим.

Мета статті - з'ясувати моделі фрінансування закладів вищої освіти у країнах Європи.

Виклад основного матеріалу дослідження 3 повним обґрунтуванням здобутих наукових результатів. На переконання Н. de Boer, B. Jongbloed, «моделі фрінансування призначені не лише для розподілу ресурсів на визначені цілі, але все частіше використовуються як інструменти врядування або управління (наприклад, підзвітність)» [2].

J. Salmi, A. Hauptman [4] виділили інноваційні моделі розподілу фінансових ресурсів на вищу освіту, що включають (табл. 1) [4, с. 84]:

- фрінансування на основі пропозиції, або пряме фрінансування закладів вищої освіти;

- фінансування на основі попиту, або непряме фрінансування закладів вищої освіти.

J. Salmi запропонував дві моделі фрінансування закладів вищої освіти [1, с. 308]:

- фрінансування на основі пропозиції;

- фонансування на основі попиту.

Перша модель відображає традиційну модель фрінансування, спрямовану на підтримку реалізації вищою освітою фрункцій суспільного блага і забезпечення рівних можливостей доступу до вищої освіти. За такої моделі фрінансування закла- дів вищої освіти здійснюється 3 державних джерел, виходячи 3 потреб «на вході» (input-based allocation) і не враховуючи критеріїв результативності. Така модель діяла у Німеччині і Франції.

Друга модель передбачає, що система фрінансування ґрунтується переважно на ринкових механізмах, відповідно до яких державні фрінансові ресурси «слідують за студентом», а не спрямовуються безпосередньо до закладів вищої освіти. Інструментами реалізації такого підходу є гранти, стипендії, студентські кредити, ваучери. За такого підходу споживачі послуг вищої освіти стають орієнтиром і рушійною силою реформ у сфрері вищої освіти. Такий механізм сприяє більшій ефективності закладів вищої освіти з точки зору вартості пропонованих послуг у сорері вищої освіти, крім того, його можна застосовувати незалежно від джерел надходження ресурсів. Така модель діє у Великій Британії, Фінляндії.

F. Ziegele виокремив три виміри (pillars) моделей фрінансування у країнах Європи [3, с. 73]:

- "Basic funding" (базове фрінансування);

- "Performance-oriented funding" (результаторієнтоване фрінансування);

- "Innovation-/profile-oriented funding" (інноваційно-/профрільно-орієнтоване фрінансування).

Метою "Basic funding" (базового фрінансування) $€$ забезпечення передбачуваного та надійного орінансування, що покриває основну частину операційних витрат від основної діяльності закладів вищої освіти (викладання, дослідження) [5, с. 31]. Таке фрінансування надається у вигляді блокового гранту. Інструментами фрінансування $€$ такі [6]:

- "historical funding" (фрінансування на історичній основі/історично визначеного розподілу);

- "input-oriented formula (study places)" (срормула фрінансування 3 вхідними показниками/ навчальними місцями, зокрема кількістю студентів);

- "performance agreements" (контракти за результатами діяльності);

- "vouchers" (ваучери).

Таблиця 1

Інноваційні моделі розподілу фінансових ресурсів у сфері вищої освіти [1, с. 306]

\begin{tabular}{|c|c|c|}
\hline & $\begin{array}{c}\text { Negotiated Allocations } \\
\text { (узгоджений розподіл на основі переговорів) }\end{array}$ & $\begin{array}{l}\text { Competitive Mechanisms } \\
\text { (конкурсні механізми) }\end{array}$ \\
\hline $\begin{array}{c}\text { Direct funding } \\
\text { (supply-side) } \\
\text { Пряме фрінансування } \\
\text { (на основі пропозиції) }\end{array}$ & $\begin{array}{c}\text { Performance contracts } \\
\text { (контракти за результатами діяльності) } \\
\text { Performance set-asides } \\
\text { (виконання планових потреб) }\end{array}$ & $\begin{array}{l}\text { Competitive funds } \\
\text { (конкурентні фронди) }\end{array}$ \\
\hline $\begin{array}{c}\text { Indirect funding } \\
\text { (demand-side) } \\
\text { Непряме орінансування } \\
\text { (на основі попиту) }\end{array}$ & $\begin{array}{c}\text { Income-contingent student loans } \\
\text { (студентські кредити на основі доходів) } \\
\text { Human саріtal contracts (контракти } \\
\text { на людський капітал) } \\
\text { Universal vouchers } \\
\text { (універсальні ваучери) } \\
\text { Lifelong learning ассоunts (рахунки для навчання } \\
\text { впродовж життя) }\end{array}$ & $\begin{array}{l}\text { Merit-based vouchers (ваучери } \\
\text { на основі досягнень студентів) }\end{array}$ \\
\hline
\end{tabular}


Метою "Performance-oriented funding" (результаторієнтованого фрінансування) $€$ створення орінансових стимулів для закладів вищої освіти завдяки тому, що через заохочення конкуренції за досягнення бажаних результатів діяльності передбачається винагорода. Основним інструментом фрінансування $€$ "output-, performance-oriented formula" (формула фрінансування з вихідними показниками, орієнтована на результати діяльності).

Механізми такого фрінансування передбачають винагороду закладу вищої освіти ex post (фрактично) за досягнуті результати [3, с. 74]. У системах вищої освіти застосовуються механізми розподілу цього фрінансування у вигляді фрормули, що згруповані таким чином:

- на діяльність 3 викладання - 3 частковою орієнтацією на результат (критерії у фрормулі, пов'язані із кількістю випускників);

- на діяльність із дослідження - $з$ частковою або повною орієнтацією на результат (критерії у орормулі, пов'язані із кількістю публікацій та залученого зовнішнього фрінансування).

Innovation-/profile-oriented funding (інноваційно-/профрільно-орієнтоване фрінансування) має такі споріднені назви [5, с. 32]: "targeted/earmarked funding" (цільове фрінансування), "competitive funding" (конкурентне орінансування), "strategic funding" (стратегічне фрінансування), "project-based funding" (проєктне орінансування), "ехcellence initiatives" або "centers of excellence" (ініціативи досконалості або центри досконалості). Це фрінансування спрямоване на стимулювання інновацій, дослідницької (іноді викладацької) досконалості або розвиток інституційних просрілів.

До інструментів фрінансування відносять:

- "performance contracts" (target agreements, performance agreements);

- "competitive funds" - фрінансування, розміщене на конкурентній основі (наприклад, у Великій Британії фрінансування діяльності закладів вищої освіти з обміну знаннями 3 метою забезпечення подальшого зростання економічної і соціальної вигоди - "Higher Education Innovation Fund" [7]);

- "excellence schemes" - програми проєктного фрінансування для проведення стратегічних досліджень.

Експерти Світового Банку визначили такі критерії належної моделі фрінансування (good financing model), як [8, с. 55-59]:

- стратегічна орієнтація

(strategic orientation) передбачає підтримку національних стратегій та інституційних профрілів, тобто фрінансування має сприяти розвитку диференціації та специорікації інституційних профрілів;

- орієнтація на стимули (incentive orientation) передбачає:

а) створення системи винагород/санкцій за досягнення/недосягнення показників результа- тивності, а також недопущення фррагментарності стимулів;

б) створення конкурентного середовища через запровадження результат-орієнтованого фрінансування університетів;

в) збалансування ex-post та ex-ante орієнтації на результати передбачає забезпечення симулів шляхом фрінансування через: по-перше, target agreements (ex ante - за досягнення майбутніх результатів), по-друге, formula funding (ex post - за вже досягнуті результати);

- стійкість (sustainability):

а) стабільність - модель фрінансування (особливо державного фрінансування) має включати компоненти базового фрінансування (критерії кількості навчальних місць або персоналу) основної діяльності університету;

б) забезпечення можливості довгострокового планування для розроблення, прогнозування та планювання бюджетів закладів вищої освіти;

в) врахування різниці витрат у різних галузях знань (вартість підготовки випускника у сорері інженерії набагато більша, ніж у сорері бізнесу);

г) забезпечення диверсиорікації ризиків та ризик-менеджмент через диверсиорікацію ресурсів;

- легітимізація (legitimisation):

a) баланс між вимірами моделі фрінансування (basic funding, performance-oriented funding, and innovation-oriented funding);

б) прозорість фрінансувння та забезпечення підзвітності закладів вищої освіти;

в) справедливість розподілу фрінансування (у разі студентського фрінансування);

- автономія та гнучкість (autonomy and flexibility):

а) виділення фрінансових ресурсів однією сумою (блок-грант);

б) гарантія академічної свободи (розробка спільних освітніх програм із роботодавцями, можливість уряду визначати кількість студентів у різних галузях знань або університетах, фрінансування досліджень на конкурсній основі через результативні угоди);

в) адекватний рівень фрінансування на основі фрінансового регулювання, що має забезпечити прозорість, а не обмежувати гнучкість;

г) гарантія автономії внутрішнього розподілу ресурсів, що має бути визначена університетом і не підлягає регулюванню державою. Це дасть змогу пов'язати систему стимулів зі стратегічними пріоритетами університету;

ґ) диверсисрікація джерел надходжень;

- практична реалізація (practical feasibility):

a) використання актуальних інфрормаційних даних (на національному та інституційному рівнях);

б) адміністративна ефективність (забезпечення мінімізації трансакційних витрат); 
- врахування методологічних стандартів;

- узгодженість фрінансування та управлінських підходів - застосування інструментів врядування у сорері вищої освіти має фрормувати узгоджений підхід до управління системою вищої освіти.

Висновки із цього дослідження і подальші перспективи у цьому напрямі. У європейських країнах відбувається ресрормування систем фрінансування вищої освіти. Це знаходить свій прояв у трансорормації способів розміщення державних фрінансових ресурсів, зокрема частина яких надається студентам у формі державних субсидованих позик або податкових пільг. У країнах Європи наявні моделі фрінансування закладів вищої освіти на основі пропозиції та на основі попиту. Виокремлюють три виміри (pillars) моделей фрінансування: "Basic funding" (базове орінансування); "Performance-oriented funding" (результат-орієнтоване фрінансування); "Innovation-/profile-oriented funding" (ынноваційно-/профрільно-орієнтоване орінансування).

3'ясовано, що урядам необхідно пам'ятати про головні принципи належного фрінансування, якими можна керуватися в процесі проведення фрінансової політики [1, с. 316-317]: мобілізувати достатні ресурси, державні та приватні, щоб рівною мірою відповідати на потреби кількісного зростання та поліпшення якості; гарантувати, що розподіл витрат обов'язково супроводжується наданням адекватної допомоги студентам; використовувати фрінансові механізми, засновані на оцінці результатів, і по можливості розподіляти ресурси на конкурсній основі; забезпечувати повну сумісність різноманітних інструментів орінансування; дотримуватися принципів прозорості під час розробки та використання всіх фрінансових механізмів (постановка чітких політичних цілей, правил і процедур розподілу ресурсів).

\section{БІБЛІОГРАФІЧНИЙ СПИСОК:}

1. OECD (2009). Higher Education to 2030. Volume 2: Globalisation. URL: https://www.oecd-ilibrary. org/education/higher-education-to-2030-volume-2globalisation_9789264075375-en.

2. Harry de Boer \& Ben Jongbloed. Report for the Dutch Ministry of Education, Culture and Science. Policy reform, performance-based funding and performance agreements in thirteen counties. 2014. URL: https://ris.utwente.nl/ws/portalfiles/portal/5139116/ PBF+and+PA+report.pdf.

3. Ziegele F. European trends in performanceoriented funding. In Leadership and governance in higher education: Handbook for decision-makers and administrators, / ed. S. Bergan, E. Egron-Polak, J. Kohler, and L. Purser, 2013. Vol. 1, pp. 71-88. Berlin : Raabe.

4. Salmi J., Hauptman A. Innovations in tertiary education financing: a comparative evaluation of allocation mechanisms (English). Education working paper series. 2006. No. 4. Washington, DC : World Bank. URL: http://documents.worldbank.org/curated/ en/965151468314986713/Innovations-in-tertiaryeducation-financing-a-comparative-evaluation-ofallocation-mechanisms.

5. Arnhold, N., Kivistö, J., Vossensteyn, H., Püttmann, V., Ziegele, F. World Bank Support to Higher Education in Latvia : Volume 2. Internal Funding and Governance. World Bank, Washington, DC. 2018. URL: https://openknowledge.worldbank.org/ handle/10986/29739.

6. Ziegele F. Strategic Funding (and the Role of Performance Agreements). 2017. URL: https://www. che.de/cms/?getObject=307\&getLang=en\&strAction=s how\&PK User=15.

7. Education Innovation Funding scheme. URL: https://re.ukri.org/knowledge-exchange/the-highereducation-innovation-fund-heif.

8. Arnhold N., Kivistö J., Vossensteyn H., Weaver J., Ziegele F. World Bank Support to Higher Education in Latvia. Volume 1. System-Level Funding. World Bank, Washington, DC. 2018. URL: https://openknowledge. worldbank.org/handle/10986/29740. 